\title{
Impacts of Topsoil and Surface Water Salinity on Agriculture: A Study at Paikgachha, Khulna
}

\author{
Md. Ferdous-ur-Rahman Bhuiya ${ }^{1}$, Md. Humayun Kabir ${ }^{1}$ and Muhammad Ferdaus ${ }^{2}$
}

\author{
${ }^{1}$ Department of Geography and Environment, University of Dhaka, Dhaka 1000, Bangladesh \\ ${ }^{2}$ Postgraduate Programs in Disaster Management (PPDM), BRAC University, Dhaka 1212, Bangladesh
}

Manuscript received: 25 September 2020; accepted for publication: 22 January 2021

\begin{abstract}
The study investigates top-soil and surface water salinity and its impact on farming practices. Sholadana Union of Paikgachha Upazila under Khulna district is selected for the study, where there is an increasing dominance of shrimp farming aquaculture. The study is based on primary data collected through field survey and laboratory analysis of soil and water samples in two different time periods (May and September), household questionnaire survey, Focus Group Discussions (FGDs) with key stakeholders and salinity data of both soil and water collected from Soil Resource Development Institute (SRDI). Both soil and water salinity levels were tested through chemical analysis in the laboratory. The study shows that salinity level has been increasing over the years. Dry season salinity in both water and soil remain high in May $(31.1 \mathrm{dS} / \mathrm{m}$ and $16.09 \mathrm{dS} / \mathrm{m}$ respectively), while in September $1.4 \mathrm{dS} / \mathrm{m}$ and $0.3 \mathrm{dS} / \mathrm{m}$ respectively. Dry season salinity is extremely higher than the standard level $(<0.75 \mathrm{dS} / \mathrm{m})$. Due to the increased salinity level, significant impacts have been observed in farming and freshwater aquaculture practices, such as- loss of soil fertility and decreasing rice productivity and loss of freshwater species etc. Though salinity level remains favourable to farming practices in wetter months, stagnant of surface water elsewhere becomes an impediment. However, to maintain salinity level for both soil and water for farming and freshwater aquaculture, any further conversion of farming lands into shrimp ponds should be stopped.
\end{abstract}

Keywords: Topsoil and surface water, salinity, Agriculture, Freshwater aquaculture, Adaptation strategies

\section{INTRODUCTION}

Salinity intrusion is an increasing problem in the coastal region Bangladesh. The scenario of this problem reaches in acute level especially in the dry season due to tremendous reduction of freshwater flow, shrimp aquaculture, deforestation etc. (Brammer, 2014). Climate change related hazards like sea-level rise, cyclone, storm surge and tidal movement are also reported to contribute to increased salinity. Various climatic, man-made, socio-economic, and political reasons are responsible for increasing salinity in the coastal region in Bangladesh (Chowdhury and Ali, 2019). The impact of sea-level rise also varies depending on geographical location as well as socio-economic factors like poor infrastructure, population density, inappropriate policy, and inefficient technology. The coasts that already meet the threshold limit of the tidal movements are highly vulnerable to salinity intrusion in the dry season when a slow flowing condition remains in the river. The freshwater of the river

Corresponding author: Humayun Kabir

E-mail: nhk.geoenv@du.ac.bd

DOI: $\underline{\text { https://doi.org/10.3329/dujees.v8i2.54836 }}$ becomes insufficient to counterpart salinity that intrudes in river water through tidal activities. The withdrawal of freshwater from the upstream river for irrigation, decreasing rainfall during the dry season and sea-level rise due to climate change have a strong influence over freshwater distribution and tidal penetration that are remarkable evidence for salinity intrusion (Rahman, 2019). Salinity intrusion affects freshwater availability and deteriorates usability of drinking and irrigation water distribution. Kabir and Eva (2014) reported that shrimp farming is one of the major reasons of increasing salinity in the southwestern coastal area, and thus the local environment is being damaged due to shrimp aquaculture. Salinity intrusion has also caused colossal negative effects to the local vegetation and particularly to production of rice and vegetables (Kabir and Eva, 2014).

The current level of salinity has already put a threat to the crop production and a significant yield loss has already been observed in the dry season. It was warned that the impact of saline water intrusion in estuary and underground water is likely to be accelerated by sealevel rise, land subsidence and low flow river condition (MoEF, 2005) and predicted 1-meter sea-level rise at the end of the century which would affect $17.5 \%$ of the total landmass of the country. It indicates that sea-level 
rise in future will bring further land inundation and saline water will intrude to more inland. In another study, Tooley and Dominey-Howes (2008) reported that storm surge induced inundation and floods may have significant impacts including increasing deaths and injuries of the coastal inhabitants and their livestock, damage and destruction of agricultural lands, damage to food stocks and seeds, settlements, infrastructure etc. due to high level of salinity.

At least $20 \%$ of net cultivable land is affected by different degrees of salinity (Karim et al., 1990; Khanom and Salehin, 2012). Landuse for agricultural activities in these areas is lower and is significantly lower than the country's average cropping intensity. Salinity causes unfavourable environment as well as hydrological situation that restrict the normal crop production throughout the year. In the saline prone areas, mainly transplanted aman rice is grown which experiences very low yield. Chowdhury and Ali (2019) reported that given increasing salinity in the coastal region, several mitigation approaches including soil reclamation, agronomic management strategies can be adopted. However, though a little to no effort has been given to reduce salinity intrusion in the past, it has become necessary now to take steps against it to enhance or maintain crop productivity and save public health.

Huq et al. (2015) explored the agricultural productivity with increasing vulnerability of the coastal region of Bangladesh and stated that the coastal area of Bangladesh is ecologically rich because of the combination of coastal mangrove forests, tidal estuaries, and productive agricultural lands. Coupled with local people's low socioeconomic status, the impacts of climatic events like cyclones, storm surges and tidal flooding eventually negatively affect coastal farmer community regarding their livelihood, income opportunities, education, and food security. Cyclone induced surge is also reported to be a major impediment in the coastal belt of Bangladesh for achieving food security (Paul, 2019). Climate change is one of the main reasons behind salinity intrusion. As a result, productivity of agricultural crops and biodiversity are declining due to loss of habitats (Huq et al., 2015).

Due to increasing salinity level, lives and livelihoods are becoming difficult in the coastal region since there has been a gradual decrease of safe drinking water. The salinity problems become even more acute for the poor people. Women and adolescent girls are usually tasked with collecting saline-free drinking water from distant sources. In some areas, nearby water sources are all affected by high amount of salinity, so they must travel long distances on foot every day to fetch drinking water. The pregnant and lactating women find it very hard to collect water due to their physical condition (Rahman, 2019). Women and girls of households normally bring water for drinking. Increasing salinity is however putting them into further trouble in making extra-time for collecting drinking water in addition to cooking, bathing, washing clothes, and taking care of the family.

Abedin et al. (2012) highlighted the impacts of salinity intrusion on public health. They also mentioned that rising salinity not only affects crop production but also normal social life in the coastal area. Salinity is regarded as the main reason behind low crop production in those areas and decreases the germination rate of most of the plants (Ashraf et al., 2002; Chowdhury and Ali, 2019; Paul, 2019). Moreover, salinity affects the growth of many fruit trees and decreases grazing land. As a result, the availability of fodder crops has reduced to a great extent resulting in the declining existence of livestock. Thus, salinity plays role in creating food insecurity in the entire coastal areas of southwestern part (Habiba et al., 2013).

\section{OBJECTIVES OF THE STUDY}

The major objective of the study is to investigate salinity intrusion in topsoil and surface water and its impacts on agriculture and aquaculture. However, the specific objectives are to-

- assess topsoil salinity intrusion in the study area and its impacts on agriculture

- assess increasing salinity level in surface water and its impacts on aquaculture

\section{MATERIALS AND METHODS}

\section{Selection of the Study Area}

Paikgachha Upazilla of Khulna district has purposively been selected for the present study being its location in the coastal region that tremendously faced prolonged water stagnation due to the super cyclone Aila in 2009. Betbunia, Vakot Mari and Char Banda villages of Sholadana Union were selected for detail study based on the suggestions of the Upazila Agriculture Officer (Figure 1). The study sites are 
located on the banks of the Kobadak River to the south and the Shibsha to the east. Though initially the inhabitants were mostly farmers, later gradually they have been forced to be involved in shrimp farming related activities with increasing conversion of farmlands into shrimp ponds. About 50 percent of the population is employed in this sector and about 70 percent people overall depend on agriculture for their livelihood (Imdad, 2021). Shrimp farming activities continue in full swing in the dry season along with some agriculture practices (mainly rice). On other hand, in the monsoon season, stagnant water remains all around due to entrance of saline water through sluice gates for aquaculture. During this season, shrimp farming becomes relatively less prevalent, while freshwater aquaculture becomes dominant.

\section{Collection of Soil and Water Samples}

The fieldwork was conducted in two phases in two different time periods (May and September 2018). First phase activities include collection of water and soil samples, field observation etc. in the month of May 2018. In the second phase in September 2018, water and soil samples were collected from the same sites. A total of 18 soil and water samples were collected from three study villages in two different periods. It is to be mentioned that the soil samples were taken from topsoil and water samples were taken from surface water bodies.

\section{Laboratory Experiments}

Water salinity was determined directly by using Electrical Conductivity (EC) meter. Soil salinity was measured by 1:1 method. At first soil samples were dried. Then $100 \mathrm{gm}$ soil was taken for EC measurement. A solution was made by $100 \mathrm{ml}$ distilled water and $100 \mathrm{gm}$ soil and then the solution is shaken for 30 minutes by a shaker. Finally, the solution is filtered by filter paper and then EC was measured by EC meter. Both layers of samples were analyzed in the laboratory of SRDI.

\section{Social Study}

In addition to collection of soil and water samples from the study areas, household questionnaire survey, focus group discussion (FGD) and key informant interview (KII) were also carried out to evaluate local stakeholders' perception on increasing salinity issues and consequences and the same time, different adaptation strategies to combat the high salinity.

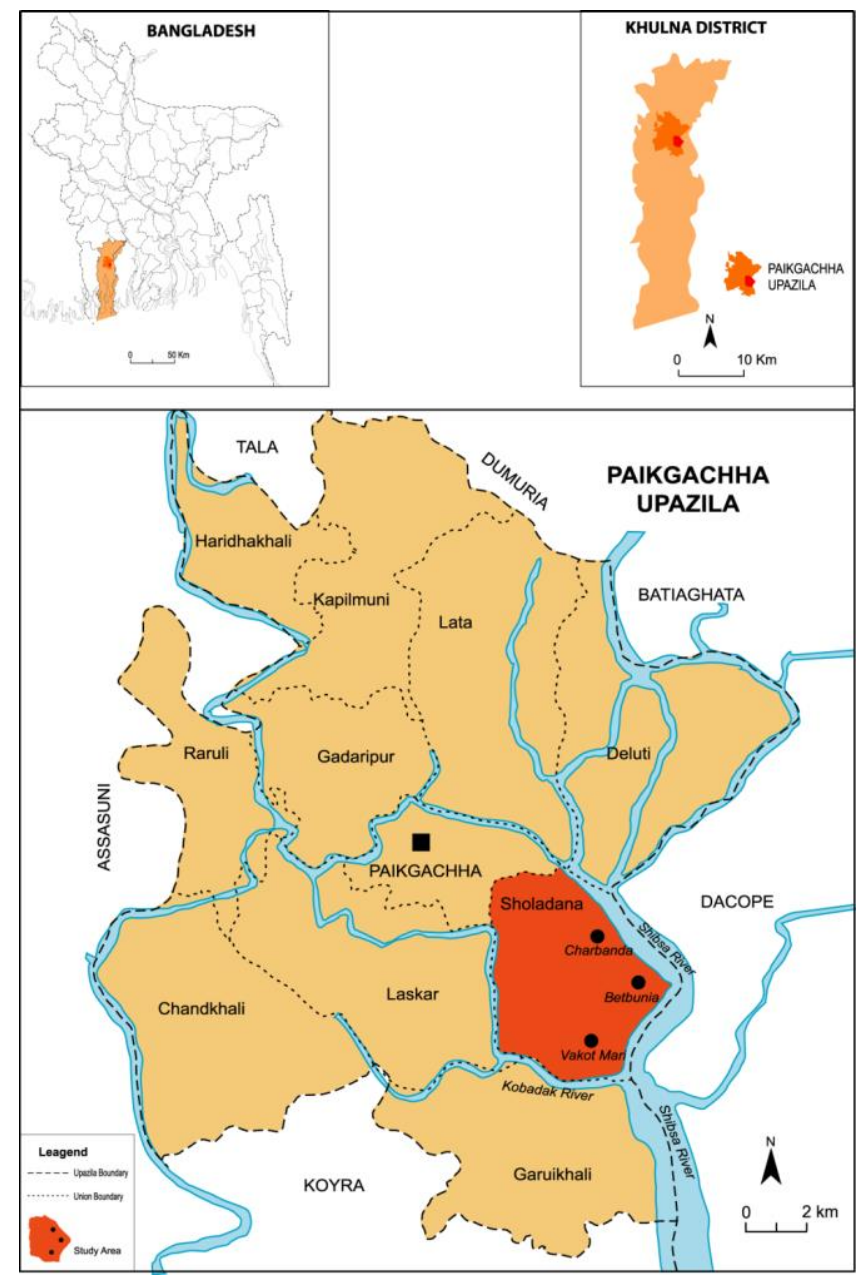

Figure 1: Location of the Study Areas

Household Questionnaire Survey: A survey with a total of 120 households with a semi-structured questionnaire was carried out. Primarily the entire inhabitants were divided into three groups (full time fishermen, aquaculture day labourers and farmers with farming day labourers). Systematic random sampling method was followed in selecting the households from these clusters.

Key Informants' Interview: To justify the outcomes from fieldworks, a total of five (5) key informant interviews were conducted. They are- Upazila Agriculture Officer, Senior Scientific Officer of SRDI, representative from the Water Development Board (Khulna), academic/researcher from NorthSouth University and local NGO official (BRAC).

Focus Group Discussion: A total of six (6) FGDs were conducted with groups drawn from different occupations, such as- subsistence farmers (2), fishermen (2), small landholders (1) and sharecroppers 
(1). Participants were actively participated in discussions regarding the salinity related problems, livelihood, agricultural production, food security and adaptation techniques applied in the locality. The data collected from FGDs were cross-examined by the interviewee from different households and KII.

\section{FINDINGS AND DISCUSSION}

\section{Salinity Level of Topsoil and Water}

Salinity levels of water and topsoil have been analyzed from primary and secondary data. Secondary data analysis shows that significant fluctuations in water salinity level of wet and dry seasons in the study area are observed during 2007-2016 (Figure 2). In 2010, average dry season salinity in water tremendously increased after the devastating cyclone Aila affected the study sites (average salinity around $17 \mathrm{dS} / \mathrm{m}$ ).

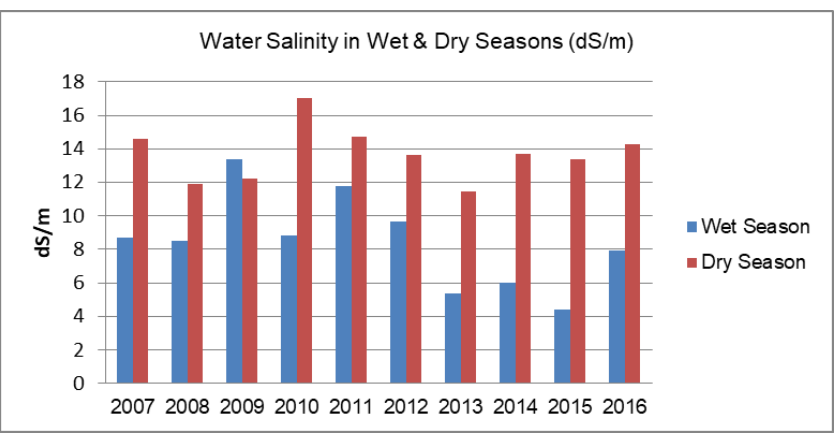

Figure 2: Average Level of Water Salinity in Wet and Dry Seasons of Sholadana Union

Source: SRDI, 2018

The relatively recent data collected from SRDI (2018) show more or less similar figure with the present study. Moreover, wet season water salinity shown in Figure 2 was around $8 \mathrm{dS} / \mathrm{m}$ in 2016, while the average water salinity level of the current study is found almost similar $(8.360 \mathrm{dS} / \mathrm{m})$. The SRDI samples were collected from the Shibsha River passing through the eastern part of the study sites. In addition, samples for the present study were collected from the surface water bodies of Soladana River.

Though, the sample collection was from different sources (water bodies) of the study area, there is a similarity among the results (Table 2 and Figure 2). Figure 3 shows topsoil salinity levels in dry and wet seasons during 2007-2016 collected from the SRDI (2018). Normally soil salinity remains lower than water bodies (Figures 2 and 3). SDRI (2018) soil salinity levels in dry season show consistence (around $10 \mathrm{dS} / \mathrm{m})$. On the other hand, average topsoil salinity in the dry season has been found just over $12 \mathrm{dS} / \mathrm{m}$ in the present study. Due to the devastating cyclones (Sidr in 2007 and Aila in 2009), both water and soil salinity in both seasons significantly increased. In the latter years, though the levels gradually slightly decreased, they have been found increasing in the recent periods. However, in both cases (soil and water) in dry and wet seasons, salinity levels are found to exist at an alarming state.

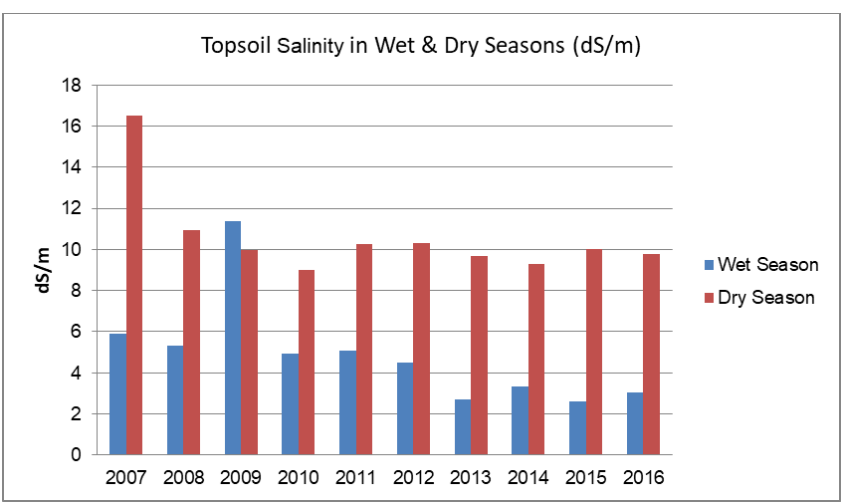

Figure 3: Topsoil Salinity of the Study Area in Wet and Dry Seasons

Source: SRDI, 2018

Laboratory analyses of the topsoil and water samples shows remarkable variation in the occurrence of salinity levels in two different periods (May and September) (Table 1 and Table 2). Table 1 shows that salinity level of soil appears to be similar at three locations in the dry seasons as does the level of water salinity. Chemical experiments show that salinity levels of soil and water significantly vary in wet and dry seasons. Soil salinity levels at three study locations (Betbunia, Charbandha and Vejatmari) in dry season are found $12.09 \mathrm{dS} / \mathrm{m}, 11.71 \mathrm{dS} / \mathrm{m}$, and $12.48 \mathrm{dS} / \mathrm{m}$ respectively. At the same time, water salinity levels of these three study locations are found $19.1 \mathrm{dS} / \mathrm{m}, 19.5 \mathrm{dS} / \mathrm{m}$, and $20.5 \mathrm{dS} / \mathrm{m}$ respectively.

Table 1: Laboratory Experiments of Soil and Water Salinity (Dry Season)

\begin{tabular}{|l|c|c|}
\hline \multicolumn{1}{|c|}{ Sites } & Soil salinity $(\mathrm{dS} / \mathrm{m})$ & Water salinity $(\mathrm{dS} / \mathrm{m})$ \\
\hline $\begin{array}{l}\text { Betbunia, } \\
\text { Paikgachha }\end{array}$ & 12.09 & 19.1 \\
\hline $\begin{array}{l}\text { Charbanda, } \\
\text { Paikgachha }\end{array}$ & 11.71 & 19.5 \\
\hline $\begin{array}{l}\text { Vejatmari, } \\
\text { Paikgachha }\end{array}$ & 12.48 & 20.5 \\
\hline
\end{tabular}

Source: Chemical experiment in SRDI laboratory, Boira, Khulna 2018-2019

The average soil salinity level in dry season remains $12.09 \mathrm{dS} / \mathrm{m}$, while in wet season the level drastically 
reduces (average $3.0 \mathrm{dS} / \mathrm{m}$ ). Average water salinity also differs in dry and wet seasons. In wet season, average water salinity remains $8.63 \mathrm{dS} / \mathrm{m}$ while it drastically increases $(19.70 \mathrm{dS} / \mathrm{m})$ in dry season, specifically in the months of April to May (Table 2). The study results also seem to be similar to other coastal areas in Bangladesh, while topsoil $(0-15 \mathrm{~cm})$ salinity in the dry season varied from 4.0 to $9.0 \mathrm{dS} / \mathrm{m}$ in moderately saline soils and from 5.0 to $12.0 \mathrm{dS} / \mathrm{m}$ in saline soils in coastal rice lands in Bangladesh (Mondal et al., 2001).

Table 2: Average Soil and Water Salinity of the Study Locations (Wet Season)

\begin{tabular}{|c|c|c|}
\hline Period & Soil Salinity $(\mathrm{dS} / \mathrm{m})$ & Water Salinity $(\mathrm{dS} / \mathrm{m})$ \\
\hline Dry & 12.09 & 19.70 \\
\hline Wet & 3.00 & 8.63 \\
\hline
\end{tabular}

Source: Chemical experiment in SRDI laboratory, Boira, Khulna 2018-2019

Interview results with households in the study area also reveal that salinity both in water and soil are increasing due to various reasons (Table 3). Increasing number of saline fishery ghers are mainly responsible for increasing salinity in water and soil as perceived by an overwhelming majority of the respondents. In addition, respondents consider that it might be triggered due to cyclonic surge. It was also observed that climate change induced sea level rise might expedite salinity. Deforestation is another issue in the study area which is also highlighted by the interviewees. Upstream freshwater flow reduction, siltation in the riverbed and over withdrawal of groundwater are other causes of increasing salinity as opined by the respondents.

Table 3: Reasons of Increasing Salinity as Perceived by the Respondents

\begin{tabular}{|l|c|c|c|}
\hline $\begin{array}{l}\text { Reasons of } \\
\text { salinity Intrusion }\end{array}$ & $\begin{array}{c}\text { Frequency } \\
(\mathrm{n}=120)\end{array}$ & $\begin{array}{c}\% \text { of } \\
\text { Responses }\end{array}$ & $\begin{array}{c}\% \text { of } \\
\text { Respondents }\end{array}$ \\
\hline $\begin{array}{l}\text { Saline fishery } \\
\text { gher }\end{array}$ & 78 & 38.61 & 65.00 \\
\hline Cyclonic surges & 45 & 22.28 & 37.50 \\
\hline $\begin{array}{l}\text { Sea level rise due } \\
\text { to climate change }\end{array}$ & 32 & 15.84 & 26.67 \\
\hline Deforestation & 20 & 9.90 & 16.67 \\
\hline $\begin{array}{l}\text { Freshwater flow } \\
\text { reduction }\end{array}$ & 13 & 6.44 & 10.83 \\
\hline Siltation & 8 & 3.96 & 6.67 \\
\hline $\begin{array}{l}\text { Over withdrawal } \\
\text { of groundwater }\end{array}$ & 6 & 2.97 & 5.00 \\
\hline Total & 202 & 100.00 & \\
\hline
\end{tabular}

*multiple responses were considered

Source: Field Study 2018-2019

\section{Impact of Salinity on Agriculture}

Sholadana Union, the study area is situated on the bank of the Shibshah River. With increasing salinity level both in water and topsoil, the productivity of agricultural crops has significantly been affected. It has been identified that the productivity of various types of rice has drastically dwindled (Table 4). The study reveals that ten years back, paddy crops like Orkoz, Patnai, Aishfall, Koijuri, Jutobalam, Gonshae, Kachla, etc. (local variety of paddy) were widely grown, while they are currently not cultivated due to increasing salinity. Rice crops that are currently cultivated are not achieving productivity that prevailed ten years back.

Table 4: Impact of Topsoil Salinity on Rice Production in the Study Area

\begin{tabular}{|l|l|l|}
\hline Type of Rice & $\begin{array}{l}\text { Currently } \\
\text { Cultivated with } \\
\text { Productivity } \\
(\mathrm{kg} / \text { bigha })\end{array}$ & $\begin{array}{l}\text { Cultivated 10 years } \\
\text { back } \\
\text { Productivity } \\
\text { (kg/bigha) }\end{array}$ \\
\hline Arkoj & 261.268 & 410.564 \\
\hline Patnai & 223.944 & 335.916 \\
\hline Aishfal & $186.62 \quad$ & 298.592 \\
\hline Koijuri & $\begin{array}{l}- \text { not currently } \\
\text { cultivated }\end{array}$ & 261.268 \\
\hline Jutobalam & $\begin{array}{l}- \text { not currently } \\
\text { cultivated }\end{array}$ & 298.592 \\
\hline Gonshe & $\begin{array}{l}\text {-not currently } \\
\text { cultivated }\end{array}$ & 261.268 \\
\hline Kasla & $\begin{array}{l}\text {-not currently } \\
\text { cultivated }\end{array}$ & 261.268 \\
\hline
\end{tabular}

Source: Field Study 2018-2019

Some local rice varieties like Koijuri, Jutobalam, Gonshae and Kasla are not grown elsewhere in the country. The study area was once widely known as rice-lands. With rising salinity, typical rice crops that are saline tolerant and hybrid have been introduced. Therefore, in addition to increasing salinity, farmers' interest in high yielding varieties has also played a role in declining cultivation trend of the local paddy crops. In terms of vegetable production, it has been observed that both quantity and productivity of vegetables have drastically declined due to increasing salinity. The respondents talked about declining productivity of spinach, red amaranth, potato, tomato etc. though their productivity was reported much higher 10 years back (Table 5). Some crops (e.g. mustard, pulses, onion, eggplant etc.) are no more cultivated in the study area. 
Table 5: Impact of Salinity Intrusion on Vegetables and Legumes Production

\begin{tabular}{|l|l|l|}
\hline $\begin{array}{l}\text { Vegetables and } \\
\text { Legumes }\end{array}$ & $\begin{array}{l}\text { Currently } \\
\text { Cultivated with } \\
\text { Productivity } \\
(\mathrm{kg} / \text { decimal })\end{array}$ & $\begin{array}{l}\text { Cultivated 10 } \\
\text { Years Back with } \\
\text { Productivity } \\
\text { (kg/decimal) }\end{array}$ \\
\hline Spinach & $7-8$ & $14-16$ \\
\hline Red amaranth & $6-7$ & $12-14$ \\
\hline Potato & $45-51$ & $57-68$ \\
\hline Tomato & $16-18$ & $23-28$ \\
\hline Kholrabi & $11-14$ & $17-20$ \\
\hline $\begin{array}{l}\text { Cauliflower } \\
\text { (pieces/decimal) }\end{array}$ & $25-30$ & $40-45$ \\
\hline $\begin{array}{l}\text { Cabbage } \\
\text { (pieces/decimal) }\end{array}$ & $20-25$ & $30-35$ \\
\hline Mustard & $\begin{array}{l}\text {-not currently } \\
\text { cultivated }\end{array}$ & \\
\hline Pulses & $\begin{array}{l}\text {-not currently } \\
\text { cultivated }\end{array}$ & \\
\hline Onion & $\begin{array}{l}\text {-not currently } \\
\text { cultivated }\end{array}$ & \\
\hline Eggplant & $\begin{array}{l}\text {-not currently } \\
\text { cultivated }\end{array}$ & \\
\hline
\end{tabular}

Source: Field Study 2018-2019

It has been mentioned earlier that farmers face difficulties due to increasing salinity in soil and water as crop yields have significantly declined. Different crop species respond to salinity differently. Some are tolerant and some are not. But the observed salinity level in the study sties has crossed the threshold for most of the crop species (e.g. beans, carrot, eggplant, onion, etc.). The relatively high plain lands in the study area are suitable as salinity is comparatively lesser than the lowlands. Results from FGDs and KIIs reveal that vegetables like spinach, red amaranth, cauliflower, cabbage etc. can be grown there. With increasing problems associated with rice, other crops and vegetables, a significant decline in the prevalence of fruit trees and other vegetation has widely been observed from the study. As a result of high salinity level, the study region has already lost several fruit trees like jujubi, lime, guava, banana, custard apples etc. On the other hand, the existence of local tree species (e.g. bain, geoa, keora, neem, sapodila, poroshponi etc.) is still found. Like agriculture, freshwater aquaculture is also severely challenged. Due to extreme freshwater flow reduction in dry season and increasing salinity, local freshwater fisheries are threatened. The productivity of freshwater fish like shol, rui, koi, punti, catfish etc. has drastically reduced. For seven months in a year
(January-July) water salinity remains highly unsuitable to produce most freshwater fish. The closed water bodies are mostly saline with different chemicals used for farming of shrimp and other nonsweet water fish. In these ponds/wetlands, freshwater fishery is unsuitable.

Table 6: Impacts of Increased Salinity as Perceived by the Respondents

\begin{tabular}{|l|c|c|c|}
\hline $\begin{array}{l}\text { Impacts of } \\
\text { Salinity }\end{array}$ & $\begin{array}{l}\text { Frequency } \\
(\mathrm{n}=120)\end{array}$ & $\begin{array}{l}\text { \% of } \\
\text { Responses }\end{array}$ & $\begin{array}{l}\text { \% of } \\
\text { Respondents }\end{array}$ \\
\hline $\begin{array}{l}\text { Drastic decline in } \\
\text { rice production }\end{array}$ & 65 & 33.85 & 54.17 \\
\hline $\begin{array}{l}\text { Extinction of } \\
\text { local vegetables }\end{array}$ & 48 & 25.00 & 40.00 \\
\hline $\begin{array}{l}\text { Extinction of } \\
\text { local fish }\end{array}$ & 36 & 18.75 & 30.00 \\
\hline $\begin{array}{l}\text { Decline of local } \\
\text { tree coverage }\end{array}$ & 16 & 8.33 & 13.33 \\
\hline $\begin{array}{l}\text { Less productivity } \\
\text { of local fruits }\end{array}$ & 14 & 7.29 & 11.67 \\
\hline $\begin{array}{l}\text { Erosion of } \\
\text { building } \\
\text { materials }\end{array}$ & 13 & 6.77 & 10.83 \\
\hline Total & 192 & 100.00 & \\
\hline
\end{tabular}

*multiple responses were considered

Source: Field Study 2018-2019

Local people encounter serious impacts due to increasing salinity both in soil and water in the study area (Table 6). Rice production has been drastically reduced due to rising salinity level as perceived by the respondents. Increasing salinity has impacted on the production of local vegetables, indigenous fisheries, fruits etc. As a result, many of the local species (vegetables, fish, fruit trees etc.) have already disappeared from the locality. Building materials get eroded with exposure to increasing salinity as opined by the respondents. However, field observation also reveals that habitat loss is being triggered by increasing salinity influencing the existence of different species of both flora and fauna.

Given the consequences of increasing salinity levels in soil and water, local farmers have been found to adjust sometimes through switching to farming of shrimp and other saline fisheries, introducing high yielding and hybrid agricultural crops and very often introducing salt tolerant variety of rice (Table 7). Field investigation also reveals that local farmers are also gradually leaving farming practices as they are getting optimum yield. Some families have been reported to 
migrate to other nearby towns and big cities as well losing agricultural lands.

Table 7: Farmers' Adjustment with Increasing Salinity Level

\begin{tabular}{|l|c|c|c|}
\hline $\begin{array}{l}\text { Adjustment } \\
\text { Mechanism }\end{array}$ & $\begin{array}{l}\text { Frequency } \\
(\mathrm{n}=120)\end{array}$ & $\begin{array}{l}\text { \% of } \\
\text { Responses }\end{array}$ & $\begin{array}{l}\text { \% of } \\
\text { Respondents }\end{array}$ \\
\hline $\begin{array}{l}\text { Switched to } \\
\text { shrimp farming }\end{array}$ & 62 & 31.47 & 26.23 \\
\hline $\begin{array}{l}\text { Introduction of } \\
\text { hybrid crops }\end{array}$ & 55 & 27.92 & 23.27 \\
\hline $\begin{array}{l}\text { Introduction of } \\
\text { salt tolerant crop } \\
\text { variety }\end{array}$ & 48 & 24.37 & 20.30 \\
\hline $\begin{array}{l}\text { Stopping crop } \\
\text { cultivation }\end{array}$ & 18 & 9.14 & 7.61 \\
\hline Migration & 14 & 7.11 & 5.92 \\
\hline Total & 197 & 100.00 & \\
\hline
\end{tabular}

*multiple responses were considered

Source: Field Study 2018-2019

\section{DISCUSSION}

The southwestern coastal area hosts millions of people, most of them are fishermen and farmers. Traditionally the inhabitants cultivate agricultural crops and used to depend on freshwater fishery. Over time, due to increasing population growth and high demand on fisheries, commercialization of fish production has widely been reported. Saline fishery, specifically shrimp production is widely observed in the southwestern area. As a result, massive deforestation took place to accommodate saline ponds/wetlands. In addition, upstream freshwater flow has drastically declined over time (Chowdhury and Ali, 2019; Brammer, 2014). The entire area as mentioned earlier being highly prone to cyclone and tidal surge, has recently experienced prolonged inundation with saline water. All these conditions are observed to have a profound impact on increasing salinity levels in topsoil and water.

Salinity levels fluctuate over the years due to occurrence of cyclones associated tidal surge. Climate change, another burning issue triggered due to many reasons, one of which is massive deforestation in the study area is also responsible for salinity intrusion. The present study has found significant rise in the magnitude of salinity both in water and soil. Productivity of local crops particularly different varieties of rice and other crops has significantly reduced due to high topsoil salinity. Therefore, both the farmers and fishermen (major user groups) have been encountering tremendous problems in crop farming and aquaculture. The gradual decline in crop production results in ultimate food insecurity in the entire belt. The local vegetables traditionally cultivated in the area are seldom grown. The existence of local fruit and other trees is also not visible. On the other hand, commercial aquaculture of saline fish is widely practiced, while most of the local people are extremely struggling with low productivity of rice and other crops. A small part of the local inhabitants is gradually interested in cultivating high yielding varieties of crops and commercial aquaculture.

\section{CONCLUSION}

The southwestern part of the country being prone to regular tropical cyclone associated with tidal surge. The areas exposed to the Bay of Bengal are naturally prone to high salinity. Geographically this region is also influenced by natural upstream flow of freshwater throughout the year resulting in the creation of brackish water which is suitable to mangrove vegetation and associated habitats. Over time, with gradual increase of human habitation in the entire region, massive deforestation has taken place because of expansion of agricultural activities and human settlements. To protect increasing human population, a number of polders were constructed in the region. Due to the occurrence of several recent devastating cyclones (e.g. Sidr, Aila etc.), the entire southwestern part experienced prolonged clogging with saline water. Therefore, extreme freshwater flow reduction, massive deforestation, clogging of saline water due to cyclonic surges and commercialization of saline fisheries through artificial intrusion have significantly contributed in the rise of salinity levels both in wetlands and topsoil. The study area being part of the southwestern region is no exception. Traditional agroforestry has widely been changed whilst commercial fisheries become gradually lucrative to a very tiny fraction of people who can be identified as absentee influential. The present study reveals that saline aquaculture has widely been propagated in the entire region gradually wiping out the local freshwater habitats and traditional agroforestry. However, with increasing salinity in water and topsoil, local people have also been adjusting with the changing situation by introducing high yielding varieties of rice and other crops though many of the local species have either gone extinct or declined in productivity. Integrated 
landuse practice, regulation of saline water intrusion for shrimp aquaculture, maintenance of the traditional agroforestry etc. can be regarded as the solution of increasing salinity intrusion in the area.

\section{REFERENCES}

Abedin, M., Habiba, U. and Shaw, R. (2012). Impacts of Salinity, Arsenic and Drought in South-western Bangladesh, in R. Shaw and P. Tran (ed.) Environment Disaster Linkages: Community, Environment and Disaster Risk Management, Emerald Group Publishing Limited, pp.165-193.

Ashraf, M.Y., Sarwar, G., Ashraf, M., Afaf, R. and Sattar, A. (2002). Salinity induced changes in aamylase activity during germination and early cotton seedling growth. Biologia Plantarum, 45(4), 589-591.

Brammer, H. (2014). Climate Change, Sea-Level Rise and Development in Bangladesh, University Press Limited, Dhaka.

Chowdhury, I.F. and Ali, M. H. (2019). Salinity: A Silent Threat on Crops in the Coastal Areas of Bangladesh, in H. Khatun, A. Baqee and H. Kabir (ed.), People at Risk; Disaster and Despair, Dhaka: Disaster Research Training and Management Centre, University of Dhaka.

Habiba, U., Shaw, R. and Hasan, A.W.R. (2013). Drought Risk and Reduction Approaches in Bangladesh, in R. Shaw, F. Mallick and A. Islam (ed.). Disaster Risk Reduction Approaches in Bangladesh, Springer, Japan.

Huq, N., Hugé, J,. Boon, E. and Animesh, K. (2015). Climate Change Impacts in Agricultural Communities in Rural Areas of Coastal Bangladesh: A Tale of Many Stories, Sustainability 7(7): 8437-8460.

Imdad, M.P. (2021). Revitalising Bangladesh's Agriculture Sector, The Daily Star, 14 April, Dhaka.

Islam, M. S., and Haque, M. (2004). The Mangrovebased Coastal and Near Shore Fisheries of Bangladesh: Ecology, Exploitation and Management. Reviews in Fish Biology and Fisheries, 14 (153-180).
Kabir, M. H. and Eva, I. J. (2014). Environmental Impacts of Shrimp Aquaculture: The Case of Chandipur Village at Debhata Upazila of Satkhira District, Bangladesh, Journal of Asiatic Society Bangladesh, 40 (1): 107-119.

Karim, Z., Hussain, S.G and Ahmed, M. (1990). Salinity Problems and Crop Intensification in the Coastal Regions of Bangladesh, BARC Soil Publication, No. 33, Dhaka, p. 63.

Khanom, S. and Salehin, M. (2012). Salinity Constraints to Different Water Issues in Coastal Area of Bangladesh: A Case Study, Bangladesh Journal of Scientific Research, 25(1): 33-42,

MoEF (2005). National Adaptation Programme of Action (NAPA), Ministry of Environment and Forests, Government of the People's Republic of Bangladesh.

Mondal, M.K., Bhuiyan, S. I. and Franco, D.T. (2001). Soil Salinity Reduction and Prediction of Salt Dynamics in the Coastal Ricelands of Bangladesh, Agricultural Water Management, 47 (1): 9-23.

Paul, S.K. (2019). Post Cyclone Household Food Security in Coastal Bangladesh, in H. Khatun, A. Baqee and H. Kabir (ed.), People at Risk; Disaster and Despair, Dhaka: Disaster Research Training and Management Centre, University of Dhaka.

Rahman, F. (2019). Top-soil Salinity Intrusion: Impact on Agriculture and Adaptation Strategies, An Unpublished Master's Thesis, MSDM, Department of Geography and Environment, University of Dhaka.

SRDI (2018). Soil and Water Salinity of Paikgachha Upazila, Khulna, Soil Resource Development Institute, Ministry of Agriculture, Government of the People's Republic of Bangladesh.

Tooley, M. and Dominey-Howes, D. (2008). Coastal and Sea-Level Changes Storms and Floods, in S. M. N. Amin (ed.). Studies on Coastal Environments in Bangladesh, A H Development Publishing House, Dhaka. 